\title{
CARRINHEIROS: COTIDIANO E ITINERÁRIOS URBANOS DE CATADORES DE LIXO DA VILA CRUZEIRO EM PORTO ALEGRE
}

Marco Antonio Carvalho Natalino

Cornelia Eckert (orientação)

O presente estudo tem por objetivo estudar o cotidiano e os itinerários urbanos de carrinheiros (também conhecidos como papeleiros), moradores da Vila Cruzeiro de Porto Alegre. Trata-se de um grupo social pertencente às classes populares, que moram em território valorado negativamente no contexto urbano porto-alegrense. Tendo por ofício a coleta de lixo das ruas e calçadas em bairros vizinhos à sua moradia, os carrinheiros cotidianamente estão em situação de interação com atores sociais dotados de diferente visão do espaço social da metrópole. Nas ruas e avenidas, bairros e redes sociais, suas interações são mediadas não só pelo olhar inquisidor de moradores e pelo confronto tenso com motoristas; também se constituem na interação direta entre os carrinheiros e a metrópole, pelo lixo que esta produz. Dessas relações emergem redes de sociabilidade e reciprocidade que permitem aos carrinheiros manter seu modo de vida, mas também formas de estigmatização, violência física e simbólica, exclusão e precarização das condições de existência dos mesmos.

$\mathrm{O}$ universo de pesquisa se complexifica ao situarmos o caso específico desse grupo social no contexto amplo do movimento social dos catadores de lixo, dos interesses políticos da prefeitura porto-alegrense, da questão ambiental, das relações de trabalho subjacentes, e da ação de diversas organizações e entidades envolvidas com esses temas. Por outro lado, essa pesquisa busca enriquecer a compreensão da situação dos carrinheiros não apenas enquanto agentes que se colocam em determinada estrutura social. Através de uma análise mais detalhada do meu principal informante, Seu Luís, construído enquanto personagem para essa pesquisa, a subjetividade de um carrinheiro torna-se prisma por onde interpretar o contexto mais amplo. Interpretação essa que não é apenas a análise do pesquisador dotado de 
autoridade etnográfica, mas também um diálogo entre duas visões de mundo que se cruzam (CLIFFORD, 2002).

Por último, a análise se volta para uma tentativa de síntese das duas abordagens em questões como a relação dos catadores de lixo com seus clientes, a abordagem dos clientes pelos carrinheiros, a criação de novas formas de sociabilidades no espaço urbano, e a condição do carrinheiro como outro do homem urbano de classe média. Assim, primeiramente são tratadas as questões do lixo, da situação de trabalho, e dos agentes externos que atuam com essa problemática; em seguida, é enfatizada a etnografia do cotidiano na vila, a construção do personagem de Seu Luís, e as visões sobre os agentes externos; por último, analisa-se as sociabilidades e reapropriações do espaço em decorrência da atividade dos carrinheiros.

\section{A pesquisa na cidade}

A pesquisa se insere na área de conhecimento da antropologia urbana. O urbano enquanto problemática sociológica foi preocupação de toda uma tradição que remonta a Simmel e Weber, passando pela Escola de Chicago, e que no Brasil foi retomada por antropólogos como Gilberto Velho (VELHO, 1994). A cidade, habitat característico do homem moderno, é em si parte integrante indissociável da construção da modernidade enquanto fenômeno social.

Nessa direção, pesquisar numa grande metrópole brasileira é revelador das próprias contradições de uma certa utopia iluminista, baseada no império da razão e da ciência; a libertação do homem de suas necessidades materiais pela abundância produzida via o avanço da razão técnica nos mais diferentes campos do mundo da vida não se concretizou. Durante todo o século XX e mesmo no século XIX, floresceu uma literatura crítica dessa utopia, fruto de um certo desencantamento com os rumos da vida moderna (ver, por ex., HUXLEY, *, s.n.).

Na Vila Cruzeiro de Porto Alegre, assim como em qualquer favela brasileira, a cidade revela-se plural em seus meios, modos e estilos de vida. Assim, o estudo do cotidiano das populações pertencentes às classes populares é rico em apontar-nos os seus valores, sua visão de mundo, seus horizontes cognitivos; ainda mais, evidencia como, utilizando-se de uma razão prática economicista criativa, essas populações conseguem driblar a rigidez da estrutura 
social através de suas artes de fazer (DE CERTEAU, 1996).

Uma certa arte de fazer é objeto da pesquisa; a dizer, dentro da área da antropologia urbana, utilizo a tradição intelectual em torno do tema do cotidiano, através do método etnográfico, para compreender o fenômeno dos carrinheiros. Catadores de lixo reciclável, eles trabalham de forma autônoma, como que se equilibrando na fina linha vermelha que separa a legalidade da ilegalidade. Em seus itinerários urbanos interagem com a cidade através do lixo que ela produz, mas também diretamente com outros atores sociais, como seus "clientes" e demais habitantes do espaço social onde trabalham. Essas pessoas, pertencentes às classes médias, têm reações díspares frente aos carrinheiros, indo da mais completa estigmatização (GOFFMAN, 1988) e violência (seja simbólica, verbal ou mesmo física) à criação de laços de solidariedade, muitas vezes pautadas pela lógica do assistencialismo.

Pensando com Bachelard (apud BOURDIEU, 1994) acerca das implicações de uma ruptura epistemológica que autonomiza o espírito científico frente às problemáticas típicas do senso comum, os itinerários urbanos desses carrinheiros será pensado enquanto produtor de novas apropriações e ressemantizações do espaço social. Através do sentido outro que esses atores dão às regiões quando comparados com a apropriação dessas regiões pelos seus habitantes e habitues penso como objeto de pesquisa a atribuição de novos significados ao espaço social pelos carrinheiros em seu ofício. Para isso, penso o espaço social assim como Durkheim (1989), que, rompendo com o paradigma kantiano do espaço homogêneo sujeito à apreensão a priori pelo entendimento humano, percebe as distinções e divisões que lhe são inerentes como decorrência dos valores a esse espaço atribuído. Porém, não me atendo ao significados atribuídos, busco apreender como esse espaço é apropriado pelos mais diversos atores, tendo em vista que as ruas e calçadas de bairro são espaços projetados para o uso de outros, que não os carrinheiros. Assim, o próprio design urbano e suas implicações no uso do espaço está em jogo (GOTTDIENER, 1993); é nesse espaço urbano planejado que os carrinheiros exercem sua antidisciplina criativa. A partir daí, criam-se novas formas de sociabilidade que busco apreender através do uso de uma etnografia de rua (ver ECKERT e ROCHA, 2002). 
Utilizou-se o método etnográfico, sendo a observação participante a principal técnica de pesquisa. Foram feitas 13 visitas a campo, devidamente relatadas em diários de campo. Além disso, foi gravada uma entrevista aberta com Seu Luís (meu principal informante), baseada em um roteiro elaborado com o objetivo de abordar as questões mais relevantes que já tinha levantado até o momento.

Como dados adicionais, foi relatada em diário de campo uma ida a um centro de triagem de lixo na Cavalhada e a um aterro sanitário organizada pelo DMLU. Nesse dia, pude conversar com representantes da prefeitura, com a presidente da associação de triagem da Cavalhada e com representantes de ONG ligadas à questão ambiental sobre a questão dos catadores de lixo. Também foi coletado material publicado pela prefeitura, pelo Movimento Nacional de Catadores de Lixo Reciclável, e de diversos sites na Internet, onde foram obtidos dados e depoimentos dos mais diversos sobre os carrinheiros em Porto Alegre e no Brasil.

\section{Questões éticas e a observação participante em classes populares}

Talvez a primeira coisa que eu, estudante de ciências sociais aprendi nessa pesquisa foi o mundo que existe para além da metodologia higienizada dos manuais. Palavras como observação participante, entrevistas em profundidade, métodos qualitativos e tantas outras dizem muito pouco sobre a real questão que se coloca quando se vai a campo - como lidar com pessoas que você, de forma algo arrogante, se sente no direito de observar com o pretexto da cientificidade. Qual o direito que se dá ao antropólogo ou sociólogo para que possam penetrar na subjetividade de pessoas que eles mal conheciam, com a certeza de estar a fazer um bem, mas com freqüência fazendo algo incompreensível por parte de seus informantes? E pior, como lidar com uma situação onde constantemente o que seus "nativos" esperam é algo que você não pode dar?

Ao entrar numa vila qualquer de Porto Alegre dizendo que se é um estudante da UFRGS e que se pretende fazer uma pesquisa, não pode se esperar que o fato seja encarado com naturalidade. E quando se entra na Vila Cruzeiro através da mediação de colegas que fizeram um projeto de extensão e de certa forma forjaram uma relação com os habitantes do local algo diferente da que se pretende estabelecer, é difícil inculcar na cabeça das pessoas 
essa diferença.

Minha principal preocupação no campo foi a criação de falsas expectativas em torno de minha presença ali, alimentadas por todos em algum nível. A cultura assistencialista que pauta as relações entre populações pobres e agentes externos dotados de maior capital cultural e econômico era visível nas falas das pessoas. Até certo ponto, é comum que aquela população, com uma visão de mundo limitada pelas suas redes de relações (como a de qualquer pessoa) vejam na ação de agentes externos a possibilidade de ascensão social, e daí planejem novos projetos individuais e coletivos (VELHO, 1994). Mas quando esses projetos, que em classes populares são bem mais fluidos que em classes médias, tem por pressuposto a ajuda material e intelectual do pesquisador, algo foge do controle. Foram várias as vezes que tive que me desdobrar para esclarecer o que afinal eu fazia ali, já que não ia ajudar ninguém.

Incansavelmente, repetia que era apenas um estudante sem qualquer poder, e que não poderia fazer nada por eles; se eles não gostassem, poderiam me dizer que eu pararia com a pesquisa no mesmo momento, e não mais os importunaria. Ao que sempre vinha a resposta que não tinha problema, pois gostavam de mim e de minha companhia. Sendo assim, me sentia na obrigação de ser agradável e não importuná-los com perguntas talvez importantes para minha pesquisa, mas inadequadas numa situação de conversa. Dito de outra forma, a condição para que eu fizesse a pesquisa era que não fosse um chato impertinente.

Mas os problemas não paravam por aí. Afinal, o que fazer quando se ouve que tal casa será invadida no dia seguinte? Como fugir de situações onde as pessoas pedem algo de forma ostensiva? No primeiro caso, costumava expressar minha opinião de forma polida quando convinha, mas sempre com a ressalva de que eu não era o mais indicado a dar opinião sobre uma realidade que não conhecia; essa atitude agradava ao interlocutor, mas não necessariamente à minha consciência. No segundo caso, falava um enfático não; o interlocutor se sentia contrariado, mas após duas ou três situações parecidas todos pareciam perceber e entender que não eu não estava ali para ajudá-los.

Com meu informante principal, os problemas se intensificavam a medida que se intensificava a relação. Seu alcoolismo causava constrangimento por vezes, mas quando ele numa manhã não quis ir trabalhar para ficar bebendo no bar e conversar comigo, tive dúvidas de que estava fazendo a coisa certa. Mesmo tomando refrigerante, na esperança de que isso o fizesse se entusiasmar menos com a bebida, a questão ética não se resolve. Por fim, 
quando sua mulher o colocou fora de casa por causa da bebida, eu me tornei mais que o rapaz que o ia visitar por vezes; virei um confidente, para quem ele podia desabafar. Se com meu escasso treinamento em antropologia já tinha que enfrentar problemas suficientes, o que dizer quando tinha que me desdobrar enquanto psicólogo conjugal? No fim das contas, fazer observação participante é mais do que empregar uma técnica; é aceitar viver, compartilhar experiências com pessoas que atribuem valores e significados diferentes para o mundo em que vivemos. E para isso não há fórmula.

\section{A condição de carrinheiro}

\section{Preliminares históricas}

Durante todo o processo civilizatório, projeto inacabado da civilização ocidental (ver ELIAS, 1995), a questão da higiene foi aspecto importante. Enquanto o homem civilizado se constituía, o autocontrole e a repressão interna aos desejos se intensificava, e concomitantemente se construía uma clivagem social baseada em hábitos diferenciados (ELIAS, 1995).

Até o século XVII, essa clivagem não tinha atingido de forma central o campo da higiene e do saneamento urbano. Porém, com o crescimento metropolitano decorrente da industrialização, imensas massas vivendo na insalubridade foram se agrupando em bairros pobres nas grandes cidades como Londres e Paris, em condições de vida precárias. A propagação de doenças se dava de forma rápida, ao mesmo tempo em que se constituía uma identidade social entre esses trabalhadores pobres. No Brasil, o processo se deu de forma algo diversa, sendo a libertação dos escravos negros a principal causa para a formação dos agrupamentos urbanos pobres, que mais tarde, viriam a dar origens às favelas. Quanto ao caso da França, Russel diz:

"Segundo Alain Corbin o problema da destinação de resíduos urbanos, nas sociedades ocidentais, tornou-se objeto de interesse para a saúde pública desde aproximadamente o século XVII na Europa. A limpeza ou desodorização dos espaços públicos e privados foi sendo construída paulatinamente a partir das sugestões de médicossanitaristas concomitantemente ao crescimento populacional dos centros urbanos devido ao desenvolvimento da industrialização e à conseqüente ascensão da burguesia na França. A limpeza passou a ser almejada como forma de distinção social para a classe burguesa que pretendia legitimar seus "direitos" através da cultura, a higiene e do controle dos instintos, para estabelecer fronteiras nítidas em relação ao proletariado e em relação à aristocracia decadente, que se sustentava através da crença em uma concessão divina para o seu poder.”

(RUSSEL, 2001). 
Posteriormente, surgiram também as formas de planejamento urbano, pensouse a paisagem urbana mais a fundo, criaram-se os boulevards parisienses e a separação espacial nas cidades se institucionalizou. Tal forma de organização espacial também tomou forma no Brasil, já no século XX, em cidades como Rio de Janeiro e Porto Alegre (ver PENSAVENTO, 2000). Muito desse processo deve aos receios das camadas mais privilegiadas do contato com os pobres, devido às doenças contagiosas e àquilo que pode ser chamado de mentalidade higienista. A revolta da vacina é um caso exemplar dessa mentalidade na prática de políticas públicas para os pobres no Brasil, mas formas muito mais sutis de exercício desse poder na busca de resolver os problemas dos "sujos e maltrapilhos" se encontram tanto na história brasileira quanto também em Porto Alegre especificamente (ver CARVALHO, 1989; MAGNI, 1994).

\section{O lixo}

A atenção para o lixo na área científica começou com os estudos técnico-operacionais, se ampliou com a perspectiva ambientalista e não é suficientemente abordada pelas ciências sociais. Ao procurar material sobre o lixo e a reciclagem de materiais, é fácil encontrar trabalhos de engenheiros, biólogos, ou quando muito, pessoas ligadas a ONGs. O problema com esse último tipo de bibliografia, que é a que fornece alguma interpretação sobre a realidade, é um certo bias que muitos pesquisadores desconsideram, o que leva certos cientistas sociais a reproduzirem dentro da comunidade acadêmica o discurso dessas organizações.

Mas a questão do lixo é estrutural à nossa sociedade. A civilização do consumo se vê às voltas do problema do que fazer com os resíduos decorrentes de seu funcionamento; resíduos materiais e resíduos humanos, poder-se-ia dizer. De certa forma, o trabalho dos carrinheiros resolve parte desse problema, embora criando outras tensões, que são discutidas no decorrer do trabalho. Por agora, é importante ressaltar que o uso de parte das classes populares, que boa parte da literatura classificou como lumpen (ver ZALUAR, 1985), para recolher o lixo nas residências de classe média, é interessante como dispositivo de dominação e microdispositivo de poder. Tanto dominação político- -institucional (cuja lógica implica também em domesticar essa população), quanto poder microfísico (FOUCAULT, 1995), que age como negatividade quando diz ao catador de lixo "não, aqui não é o seu verdadeiro 
lugar”, e como positividade ao dizer "sim, você que é um homem de bem, pode pegar aquilo que eu já não mais desejo”.

Pensando mais a fundo, a interação dos carrinheiros com o lixo que a cidade produz leva a diferentes visões do espaço social, e está intimamente ligada às reações de estigma (e também de compaixão) por parte dos habitantes do bairros onde os carrinheiros coletam seu lixo. Mesmo dentro da vila, ocorre preconceito para com aqueles que vivem do lixo, considerados cidadãos de segunda classe mesmo na periferia. Para Douglas (1994), “... as crenças em poluição podem ser usadas num diálogo reivindicatório e contra-reivindicatório de status". Trabalhar com o lixo é se rebaixar, é aceitar uma posição degradante e hierarquicamente inferior na relação com as pessoas.

\section{O Trabalho}

Como já apontou Fonseca (2000), nas vilas de Porto Alegre é comum a reivindicação de status pela relação de trabalho autônoma, sem patrão. Mesmo aqueles que trabalham para alguém se justificam com histórias sobre como conseguem tirar vantagem em alguma situação.

Nesse sentido, a situação dos carrinheiros é ambígua, assim como é ambígua (ou borderline) sua presença nas ruas. Enquanto parte da literatura insiste em categorizar o trabalho em "formal" ou "informal", alguns autores buscam uma relativização da questão através do estudo da trajetória dos trabalhadores. No caso dos carrinheiros, a especificidade está na forma como esses devem se colocar perante seus clientes (categoria êmica); muitas vezes, devem agir como pedintes, estabelecendo relações bem diversas daquelas de um camelô com seu cliente, por ex. Além disso, entre os catadores de lixo há diferenciações explícitas e que alteram tanto a relação de trabalho que esses estabelecem quanto os seus rendimentos.

Há aqueles que só separam o lixo em galpões de triagem da prefeitura. Segundo informativos do DMLU, há 600 pessoas trabalhando nesses galpões cedidos pela prefeitura, que gasta $\mathrm{R}$ \$ 110.000 para equipá-los com maquinário apropriado. Setenta toneladas de lixo são recicladas neles por dia. Para se ter uma base, o total de lixo potencialmente reciclável produzido em Porto Alegre é estimado em 500 toneladas. Esses trabalhadores, associados em cooperativas ou outras formas alternativas de organização, ganham em média R \$ 350 por mês 
para quarenta a cinqüenta horas de trabalho semanal (estimativa com base em informações obtidas no galpão da Cavalhada). Em cidades do ABC paulista, onde a venda para a indústrias é facilitada, a renda chega a R $\$ 700$ por mês.

Em segundo lugar, há os carrinheiros, em número de 1.200, e que catam em torno de 100 ton/dia (estimativa do DMLU). Seus rendimentos são porém variáveis. Segundo o Centro Empresarial de Apoio a Reciclagem (CEMPRE), há em torno de 200.000 catadores no Brasil, ganhando em média de $\mathrm{R}$ \$ 100 a R \$ 150. Mas, segundo a presidente do galpão da Cavalhada, esse rendimento em Porto Alegre corresponde aos que trabalham de forma autônoma, com carrinho “alugado". Seu Luís, carrinheiro da Vila Cruzeiro, afirma tirar R\$ 600 em um mês com tranqüilidade (na verdade, isso se deve também à ajuda de familiares no trabalho).

A diferença é que enquanto alguns carrinheiros não possuem carrinho próprio, tendo que pegá-los nos ferros-velhos aonde eles são obrigados a vender o lixo, os carrinheiros com carrinho possuem maior autonomia e ganham em torno de $30 \%$ mais no preço de venda dos materiais recicláveis. Se comparado ao preço pago aos galpões, que diminuem o número de atravessadores, essa diferença chega a $100 \%$ no caso das garrafas PET, por exemplo. Ainda outro diferencial é a possibilidade de fazer carretos. Os que alugam o carrinho têm que trazer uma certa quota para os donos dos ferros-velhos, que ficam com boa parte do lucro (segundo Seu Luís, em um curso de reciclagem lhe mostraram que o preço que os ferros-velhos vendem o material é exatamente o dobro do que pagam - ou seja, o mesmo que é pago aos galpões).

Já os que têm o carrinho, podem fazer transportes pequenos e assim aumentar as rendas. Também, é comum guardar em casa os bens mais valiosos achados no lixo, e vendê-los posteriormente (um carrinheiro da Vila Cruzeiro chegou a montar um brique). Isso sem levarmos em conta a diferença entre os carrinheiros que não se associam e os que montaram uma associação, onde podem guardar o lixo em um galpão e vendê-lo em maior quantidade, por um preço maior.

Há ainda os caso dos carroceiros, que usam tração animal, e obviamente conseguem carregar mais peso. Não possuo informações sobre eles, além do fato que existe uma rixa entre estes e os carrinheiros. Uma explicação dada por Seu Luís é que os clientes acabam sempre beneficiando os que passam a pé, seja por pena ou por comodidade de lidar com uma pessoa que está passando mais devagar pela rua; os cavalos de certa forma intimidam eventuais fregueses. 


\section{Atravessadores, agentes externos e o poder público}

Os atravessadores são, segundo todos os que tive a chance de conversar, os inimigos prediletos, e causadores de todos os males que afligem ao carrinheiros. Tal percepção de certa forma sobrevive aos cálculos feitos, e é inegável que a relação de exploração perpetuada pelos donos de ferro-velho está além de uma simples relação de trabalho capitalista. Casos de espancamento de carrinheiros que não trouxeram material suficiente me foram relatados, e o lucro desses é desproporcional quando pensamos nas

condições de vida dos catadores. Sem querer demonizá-los, é de importância heurística que aja um "inimigo comum”, base fundamental para a construção de um movimento social, junto com a identidade social e objetivos compartilhados (CASTELLS, 2001).

Outros autores, como Melucci (2001), irão colocar mais restrições ao uso do termo movimento social, e nesse caso os carrinheiros seriam mais bem explicados pelo conceito de ação coletiva, o que parece adequado no grupo estudado. Entretanto, a ação política de várias organizações que tendem a fornecer recursos para a viabilização dos projetos coletivos desses atores em geral vem condicionada ao engajamento por parte deles em causas mais amplas, como o ambientalismo.

$\mathrm{Na}$ discussão latino-americana, há ainda espaço para a idéia de que os "novos movimentos sociais" surgem no cotidiano das classes populares, e que são mais do que uma luta monolítica por direitos que podem ser reivindicados frente ao Estado (ILSE-WARREN, 1993). Seriam, na verdade, uma luta pela desalienação (MARX, 1993) dessas populações em busca de espaços de socialização não corrompidos pela lógica do sistema capitalista, aonde elas poderiam manter um estilo de vida e uma cultura própria. Parece-me que essa concepção em muito converge com a idéia de invenção do cotidiano de De Certeau (1996), para quem as artes de fazer das pessoas sistematicamente burlam os microdispositivos de poder, num jogo de antidisciplina criativa onde as táticas dos atores, usados no momento exato (kairós), altera uma situação previamente estabelecida de propriedade estratégica e abre espaço para uma nova relação. É um jogo que contrabalança a estratégia (que pressupõe uma posição, um espaço, uma propriedade) dos atores dotados de maior capital.

Nesse jogo, o poder público e os agentes externos como ONGS insistem em ditar as regras, com uma visão a priori do que deveriam fazer os carrinheiros. Em conversas com 
representantes da prefeitura e do Movimento Nacional dos Catadores de Lixo, transparecia visões díspares, porém sempre cheias de pressupostos que limitavam uma relativização e uma tentativa de compreensão da condição dos carrinheiros. Insistia-se na necessidade de se organizarem através de fórmulas prontas, de se identificarem com a causa do movimento, de "participarem", como que não levando em conta as peculiaridades de cada grupo e cada sujeito, muitos dos quais são avessos a qualquer forma de organização fixa. Ou, se não têm aversão a formas organizativas como associações, já estão desencantados com a ação que ONGs e a prefeitura promoveram no local. Esse é o caso do grupo social estudado.

\section{O cotidiano do Beco do Sorrriso}

\section{Entrada em campo}

Minha pesquisa de campo se deu em sua maioria com moradores do beco do Sorriso, que faz parte da Vila Cruzeiro em Porto Alegre. Trata-se de local privilegiado quando pensamos em outras áreas de periferia, pois está a poucos metros de regiões mais valorizadas da cidade, em torno das ruas Nonoai, Teresópolis e Cavalhada, aonde se produz a maior parte do lixo "rico" que eles coletam. Digo rico no sentido que os próprios catadores dão ao termo, rico de materiais como latinha de alumínio, garrafas PET, fios de cobre, papelão, e às vezes sapatos velhos, arquivos de metal, aquecedores, e até mesmo geladeiras.

O privilégio porém é relativo apenas quanto à proximidade com a matéria-prima do trabalho. Visto do ângulo do pesquisador, entrar no beco do Sorriso pela bela rua arborizada que desemboca nele é uma experiência de alteridade, ilustrativa do chavão "Brasil-belíndia", onde a riqueza e a pobreza vivem lado a lado no campo geográfico, mas separados por uma enorme fronteira no campo dos valores simbólicos, das visões de mundo e das condições de vida.

A minha inserção em campo se deu sob este signo da alteridade entre mundos em algum sentido tão próximos. Fui apresentado à uma mãe-de-santo do local e a algumas pessoas que com ela se relacionava por colegas de curso que participavam de um projeto convivência promovido pela PROREXT/UFRGS, e que mantiveram laços com essas pessoas através do trabalho de uma professora de arquitetura. Já no primeiro dia tive a sorte de poder ir a uma reunião (algo informal) do que seria um projeto mal-sucedido de fazer uma 
associação de carrinheiros da região. Essa encontro incluía pessoas de outras partes próximas da vila, em torno da rua Otávio de Souza.

Só havia mulheres na reunião, realizada na casa de outra mãe-de-santo, o que na hora me deu uma visão errônea do gênero predominante neste trabalho (a maioria são homens), e hoje me traz algumas indagações sobre o porque da única tentativa de ação coletiva levou ao entusiasmo das mulheres e ao descaso dos homens. Uma possível explicação é a existência no local, de forma concomitante, de uma associação de mulheres atuante, e que dialogava com os mesmos atores externos (UFRGS, ONG ligada ao movimento negro) que buscavam uma solução para a questão dos carrinheiros.

Fora minha sorte inicial, as primeiras idas a campo foram um momento de ganho de confiança e de aprendizado constante sobre os ditos imponderáveis do método etnográfico. Daquilo, não me esqueço a estranheza inicial frente aos menores gestos e falas, sobre o cotidiano daquelas pessoas que estavam sempre rindo, fazendo piadas, buscando uma relação de intimidade e proximidade comigo que me desarmou, enquanto aprendiz de etnógrafo, pois imaginava ter de suar para retirar algo dos informantes. O difícil, no fim, foi no meio daquele mar de conversas e novidades manter a mente nos questionamentos que haviam me levado ali e que começavam a se delinear, sendo o objeto de pesquisa construído ao mesmo tempo em que ia me familiarizando com a redes de significado tecidas naquele grupo.

\section{Associação e desilusão}

Como sugerido anteriormente, a idéia de formar associações de catadores é bem difundida, funcionando em vários lugares e sempre conta com o apoio das entidades que trabalham com as populações da periferia, assim como o da prefeitura de Porto Alegre.

Basicamente, a idéia é conseguir um local onde montar um galpão, e comprar uma prensa de reciclagem, de forma que se possa vender o material por um preço melhor, para compradores que só compram em quantidade. Porém, na prática mil empecilhos se colocam. Cito um trecho do meu diário de campo, em que conversava com Luís e sua esposa sobre o assunto:

Conversamos sobre as associações, e Inês manifestou o desejo de ir a Caxias para o encontro dos catadores ${ }^{1}$. Ela em seguida reclamou que todos na prefeitura e na $\mathrm{ONG}^{2}$ só querem saber de reunião, sem chegar a lugar nenhum. Tinha vezes que ela ficava o dia e a noite em reunião com os secretários de Administração e de Saúde, o que fez Luís ficar com ciúmes e os dois brigarem. Para ela, a culpa é das reuniões sem razão que não chegam a lugar nenhum. 
Ela juntou gente suficiente para fazer a associação (em torno de 20), a prefeitura prometeu ajudar, mas no fim não deram o financiamento para comprar a prensa e o material de construção (eles mesmos construiriam o galpão). Segundo Inês, não se queria nada dado, eles queriam um empréstimo, que iriam pagando com o que ganham semanalmente. Com certa revolta, ela relatou que em uma reunião da ONG, foi feita uma sessão de "mentalização", que durou uma hora. Para Inês, aquilo é legal para quem tem tempo, não para quem trabalha. Em seguida perguntei se com o financiamento ela conseguiria juntar de novo as pessoas para fazer a associação - ela disse que sim, mas que agora todos tinham se dispersado, desiludidos com o tempo perdido.

Entretanto, Luís acredita que a prefeitura poderia fazer uma forma de cortar os atravessadores, de pagar o preço justo do produto, nos galpões já existentes. Quanto a trabalhar neles, é muito difícil; Inês se cadastrou há anos e nunca foi chamada. Lá eles só pegam o lixo seco do DMLU, enquanto os carrinheiros pegam também o lixo seco misturado com o orgânico, ou seja, ajudam na reciclagem, possibilitando a reciclagem de materiais que não seriam aproveitados. Para ele, o bom mesmo seria que pudessem vender o lixo para um galpão, sem atravessadores.

No caso da vila, o galpão seria atrás da casa de Dona Rosa ${ }^{3}$. Na vila, sempre se acha um espaço quando se precisa, mesmo que à primeira vista ela pareça superlotada de pessoas. Ao mesmo tempo, os projetos individuais e coletivos são sonhados, imaginados, realizados e abandonados com uma velocidade vertiginosa, a partir de novas perspectivas ou dificuldades. Assim, os projetos seguem uma lógica mais "tática" do que "estratégica", permitindo uma homologia possível ao próprio modo de vida dessas pessoas, menos baseado em uma sólida propriedade de bens e de capitais os quais podem ser utilizados a partir de um ponto fixo, e que permitiriam estratégias de longo prazo eficazes. Em posição frágil dentro do espaço social, os carrinheiros devem possuir um certo "senso do jogo" (ou habitus) mais flexível e capaz de se apoiar em posicionamentos temporários que outros agentes assumem dentro da estrutura, donde podem extrair benefícios.

De certa forma, essa mudança constante de planos e projetos ${ }^{4}$ é necessária, devido às condições de vida. Na mesma conversa, Inês me contava como pretendia juntar colegas da vila e montar um grupo de diaristas (domésticas), e que enquanto Luís ia passando com o carrinho para recolher o lixo, ele poderia ir deixando nas caixas de correio um cartão com um telefone para contato.

Assim, torna-se compreensível o desdém com que todos os carrinheiros que conversei trataram a questão de montar uma associação, após o episódio ocorrido. De um lado, havia a desilusão de duas tentativas fracassadas; de outro, a própria lógica que rege o cotidiano deles exige que não se perca muito tempo com uma idéia que não deu certo, nem se deposite todas

1 Encontro Latino Americano de Catadores de Lixo Reciclável (ELACRE). O evento ocorreu em janeiro desse ano, $\log$ o antes do Fórum Social Mundial.

2 ONG ligada ao movimento negro, cujo nome era complexo demais para ser guardado por alguém, sendo motivo de piadas.

3 Mãe-de-santo onde se realizou a reunião da associação, ainda na minha primeira ida à campo 
as fichas em uma oportunidade. A invenção do cotidiano deles se dá pelo jogo com a posição dos outros atores, seja na conquista de clientes, seja no uso do capital (simbólico, cultural ou econômico) de agentes externos para a melhoria das condições de vida (ver BOURDIEU, 1998).

\section{Artes de fazer}

Seguindo De Certeau (1996), a atividade dos carrinheiros, enquanto arte de fazer, é um modo de agir somado a um modo de pensar, derivado de uma ratio popular, sempre criativa, bricoladora. Essa expressão foi sugerida por mim a Seu Luís, que a assumiu como a que talvez melhor expresse os conhecimentos e práticas que constituem aquilo que faz, incluindo aí tanto o aspecto de como lidar com criatividade na resolução de problemas e na busca de oportunidades de ganho, quanto o de treinar o corpo (em especial olhos, mãos e pernas) para exercer a atividade de catar lixo. Trata-se de uma arte de fazer onde aquela população, que se identifica enquanto grupo pelos conhecimentos e experiências compartilhadas no trabalho, incluindo aí uma certa coesão identitária derivada da estigmatização, busca a manutenção de um modo de vida relativamente tradicional pelo manuseio daquilo que é descartado pelo homem moderno urbano.

Em seus itinerários urbanos, é sempre necessário utilizar a astúcia, a inteligência criativa. Inúmeros casos me foram relatados, onde a atitude correta no momento certo, fizeram a diferença entre um dia de trabalho onde se ganha quase nada, e um dia onde se consegue algo de valor. Por ex., Luís me relatou que em uma tarde ele passava com o carrinho na frente de uma casa onde um senhor tentava podar uma árvore. Com educação, Luís lhe perguntou se ele não gostaria que Luís fizesse o serviço, visto que ele poderia levar os galhos aparados no carrinho. Tudo acertado, Luís ganhou em duas horas de trabalho o que ele levaria dois dias para retirar em vendas para ferros-velhos.

Muitas vezes, são os conhecimentos acumulados de outras épocas que servem como subsídio para o sustento da vida. Pica-pau, carrinheiro que mora nas redondezas do Beco do Sorriso, me relatou um dia que só coletava a fiação antiga que a CEEE havia trocado recentemente nos postes. Eletricista, ele sabia quais os fios não mais eram utilizados e que

4 É possível contestar quanto ao uso do conceito de projeto nesses casos; mantenho-o com a ressalva de ser um projeto "tático", não "estratégico", mais comum às classes médias (ver VELHO,*). 
poderiam ser pegos. Como o quilo do cobre é vendido a três reais (cerca de 15 vezes mais que o quilo do papelão, por ex.), por algum tempo ele se sustentou com pouco trabalho. Esse uso de conhecimentos do tipo "faz-tudo", o biscate, é muito comum entre os carrinheiros, para não dizer obrigatório. Em certo sentido, o trabalho e a vida não estão tão separados em compartimentos estanques. Através do estudo mais detalhado de Seu Luís, poderemos aprofundar um caso.

\section{"Seu Luis"}

O personagem construído, o narrador de sua experiência vivida, sobre a qual ele reflete e interpreta, é um catador de lixo de 44 anos de idade. Ele mora na vila Cruzeiro de Porto Alegre, mais precisamente no Beco do Sorriso, é com sua segunda esposa, Inês, e já criou mais de dez crianças. Muitos são filhos deles, mas outros foram adotados, incluindo um

bebê com AIDS. É um homem orgulhoso de poder criar tantos filhos, algo que de resto parece ser um valor comum em sua vizinhança.

Nascido no interior, Luís mudou-se com os pais para Viamão, onde trabalhou por muitos anos na Caixa Econômica Estadual. Já teve problemas de drogas e também com a polícia, mas agora se diz totalmente recuperado, tirando seu gosto por "uma cachacinha". Em momentos de lazer, é comum ir a algum dos bares do beco "tomar umas" com os amigos, sem preocupações com trabalho ou tarefas domésticas. De fato muitas vezes que mantive conversas longas com ele foi em mesas de bares, aonde ele caçoava de mim por beber refrigerante.

Seu horário de trabalho é completamente flexível, a mercê do tempo e da necessidade de ganhar algo para o sustento. Mais de uma vez combinamos de fazer juntos os seus itinerários urbanos, aonde ele cata o lixo e leva em seguida aos ferros-velhos antes de voltar para casa; no final, sempre acabamos conversando em sua casa ou em um bar. Luís gosta de conversar e é afeito a comentários jocosos e irônicos, misturados a trechos de sua história de vida, sempre reinterpretados a partir de sua situação atual. Como me confidenciou, o casamento com Inês fez ele mudar profundamente, de forma que freqüentemente se remete a algo de seu passado como se fossem atos cometidos por outrem, ou por outro self dele. Entretanto, esse mesmo passado em sua memória é por vezes ativado como confirmador de seu self atual, como a dizer que ele mantém intacta desde lá sua visão de mundo particular. 
Em geral, tais lembranças são usadas como exemplos para afirmações de sua própria posição social, de pobre e morador de um barraco na vila, mas que entretanto escolheu a vida que tem, e que não trocaria por um modo mais "correto" de ser, com emprego fixo e maiores responsabilidades.

Nesse modo de vida, reivindicado como escolha por Seu Luís, diversas redes sociais se entrecruzam como forma de manutenção da existência. Dessas redes, é importante salientar a parte que tange os clientes. São eles, conseguidos através de boa lábia e senso de oportunidade, que dão relativa segurança financeira aos carrinheiros. Mantê-los é fundamental, e um bom cliente (como um grande condomínio, ou uma filial do Mcdonald's, por ex.), pode ser a diferença que bota a comida no prato, especialmente quando se criam dez crianças ao mesmo tempo. Começo a última parte com uma análise dessas redes estabelecidas.

\section{Clientes, sociabilidades e espaço urbano}

Durante todos os itinerários urbanos dos catadores, a criação de novas redes de contato entre sujeitos pertencentes a mundos distintos dentro da metrópole é um dos pontos mais ricos. A conquista dos clientes, a relações estabelecidas, a subversão do espaço público, tudo se entrelaça. Quanto aos clientes, cito trecho da entrevista com Seu Luís:

...é, eu sou cara-de-pau. Nos botãozinho ali tá escrito, “zelador”, aí eu aperto. “Ou, queria falar contigo, só um minutinho - ah, mas quem é tu? - o Luís, um carrinheiro aî". E eles vêm, e eu digo "ô meu, eu tô numa situação, uma gamiada de criança, a minha esposa doente, e eu precisava de um apoio teu, eu precisava que tu deixasse eu entrar um dia antes na lixeira". Porque tem lixeira maior que isso aqui ó, tem lixeira que tem três espaços desse tamanho $^{5}$. Sério, aqui no alto aqui tem um ó... é aquele condomínio, dezenove edifícios. É, pra saber tem dezenove prédios, cada prédio tem três andares, cada andar tem três quatro moradores.

Se o zelador simpatizar contigo, deu. Vai dez lá falar com ele, diz "não". Aí ele te vê lá na rua e... são pessoas que tu pega sempre né.

\footnotetext{
5 Referência ao quarto onde foi feita a entrevista, de aproximadamente $3 \mathrm{~m}^{2}$.
} 
Ah, é (enfático) a aparência. Eles olham assim e... "não tem". Eles botam já essa, não tem. Mas se tu chegar, "ô, tudo bom, e pá"... entendeu? "Tem uns papelão pra mim hoje, tio?". "Tem, passa aquil. Sabe eles e te dão até acesso, entrar numa sala e sair numa outra, no depósito lá nos fundos. Isso é coisa que se planta, né? Isso não é assim, chegar ali e pedir, o cara não... tem coisas que se plantam.

Tu não precisa tá bonitão. Teja ali, teja de chinelo de dedo, um jeans, com uma camisinha decente e pá. Chega lá e pá, bagulho eu sei fazer. Chega lá com um jeans bonitinho, uma blusinha bonitinha, "ô tia, não tem um jornalzinho aî" - "ah, péra aí que eu vou olhar". Agora, chega lá de casaco, num dia de calor, te balançando no portão... "não, não, não, não tem nada". Entendeu, quando tu quer uma coisa vem... tu que tem que ir criando ele

A loja é o seguinte: eu entro na loja. "Oi, tudo bom, por acaso não tem uns papelão... nós tamo procurando". Claro que a cara 6 o cara não vai me dar, o cara vai (...) (RISOS). Mas sempre bem limpo, procura andar limpo, que num dá nada. Pegar, não andar bêbado, é a primeira coisa.

Mas tu passa na frente de uma casa, tem um casal sentado na área ali. "Ô tio, ô tia, não tem jornal velho â̂" - só que tu vai perguntar... sabe, como é que eu vou te dizer... sujo, bebâdo, a primeira coisa. Porque eu bebo depois do meu serviço, (...). Aquela hora ali eu tinha chegado com louco pra tomar uma ceva...

Isso, que eu entro lá, deixam eu reciclar antes do lixeiro chegar. No caso o lixeiro chega às oito, eu vou lá às seis. Daí duas horas antes eu tô trabalhando. Que vale a pena... três vezes por semana eu ganho um salário de um cara que sofre na obra, e eu largo meio-dia, uma hora. Sabe, não me sa... me sacrifico num sentido, mas naquele de cumprir horário não. Eu vou ali e trabalho tudo o que eu posso até a uma ou duas no caso, né. Aí depois eu tenho um apoio do pessoal que recicla, que eu só trago.

Como transparece nas entrevistas, existe um conhecimento acumulado por Seu Luís sobre as formas corretas de se abordar um possível cliente. De forma algo instintiva, ele joga muito bem com sua condição de vida, de trabalhador e pobre. Articula tanto a questão da ética católica do "dar aos pobres", de inspiração franciscana, quanto a ética protestante que dá a dádiva a quem trabalha. Pode-se dizer que a raiz da questão está em uma das idéias mais caras ao cristianismo, a compaixão. Para Nietzsche (1999, pgs. 391-408), a compaixão é o traço mais característico do sentimento cristão, sendo sua característica o preceito moral de amar aos fracos, ao invés do amor aos virtuosos (característica da Grécia pré-socrática).

Para Nietzsche (1999), a compaixão é sempre hierárquica, pois ao mesmo tempo em que se ajuda ao necessitado, se revela a posição superior do que ajuda. No caso dos carrinheiros, a compaixão está exatamente em deixar que se pegue o lixo, aquilo que não mais é de serventia nenhuma, o que reforça simbolicamente o caráter hierárquico. Por outro lado, essa mesma força reforça a própria obrigatoriedade da dádiva, aparentemente opcional (ver MAUSS, 1988).

\footnotetext{
6 Referência ao papelão de maior valor de venda.
} 
Claro, como transparece na fala de Luís, a obrigatoriedade seria quebrada se fosse encontrada alguma característica "reprovável” no que pede auxílio; bebedeira, roupas muito sujas (ou muito arrumadas!), ou mesmo um tom de voz insubordinado. Embora impossível de se transcrever em texto, a voz de Luís mudava de tom sempre que imitava a forma de abordagem de um cliente; a entonação humilde era automaticamente assumida.

Se com os clientes é possível ativar táticas das mais variadas, o mesmo não se pode dizer da relação com outros agentes que disputam o mesmo espaço social; os motoristas. Xingamentos são uma constante, e os atropelamentos não são raros. Na minha primeira ida à campo, Luís tinha acabado de sofrer um acidente, onde um carro o atropelou, deixando-o incapacitado para o trabalho. Outras histórias de atropelamento me foram contadas, inclusive uma que resultou em morte. Por esse motivo, Luís reduziu seu raio de ação, não mais indo trabalhar em avenidas movimentadas como a Praia de Belas e a Padre Cacique. Segundo suas palavras, ele tem medo.

A disputa do mesmo espaço social revela assim conflitos além de criação de redes de reciprocidade; o que não pode-se perder de vista é o design desse espaço em disputa. O design urbano (LEFEBVRE, apud GOTTDIENER, 1993), resultante de um planejamento, de uma política pública, privilegia o uso do espaço público enquanto área de tráfego. O espaço público é assim espaço de fluxo, local onde não se desenvolvem sociabilidades, não se trocam experiências e não se criam significados. Ele serve como caminho até o local onde as interações ocorrem; em geral, espaços privados. Para De Certeau (1996), os itinerários urbanos são de certa forma uma antítese dessa lógica. Esses seguem uma lógica de caminhos, onde a localização se dá por locais referenciais, enquanto um espaço racionalizado, mapeado, é mais típico de uma relação de impessoalidade.

Claramente, no espaço público também ocorrem sociabilidades, porém de outro tipo; as sociabilidades de vizinhança, cada vez mais escassas, e que de qualquer forma são limitadas do ponto de vista da multiplicidade da metrópole. A sociabilidade produzida por sujeitos pertencentes a diferentes classes sociais, que apesar de terem proximidade geográfica possuem uma distância simbólica considerável, a ponto de produzir estranhamento de forma imediata, é uma questão relevante, ainda que seja levantada aqui mais como uma pergunta do que como uma resposta. 


\section{Conclusão}

Procurei trazer alguns elementos da pesquisa realizada com catadores de lixo da Vila Cruzeiro, e demonstrar como as representações que se criam sobre o espaço social em que transitam em decorrência de suas atividades é um tema relevante. Concluindo, suas múltiplas formas de interação com a cidade, através do lixo que essa produz, através dos clientes, através do conflito com os motoristas, são produtoras de novas redes de sociabilidades.

Seu modo de vida é ao mesmo tempo complementar e contraditório ao do ideal do homem citadino moderno. Os carrinheiros são frutos de nossa sociedade de consumo, ao mesmo tempo em que são a negação de alguns de seus valores. A ocupação do espaço urbano por eles é produtora de novos significados sobre esse espaço social urbano, mais próxima a idéia de táticas e itinerários urbanos do que de estratégia e planejamento ou design urbano.

\section{Referencias}

BOURDIEU, Pierre. O poder simbólico. Rio de Janeiro: Bertrand Brasil, 1998.

BOURDIEU, Pierre. El Oficio De Sociologo :Presupuestos Epistemologicos. Mexico: Siglo Veintiuno, 1994.

CARVALHO, José Murilo de. Os bestializados: o Rio de Janeiro e a República que não foi. 3a ed. São Paulo-SP: Cia. das Letras, 1989.

CASTELLS, Manuel. O poder da identidade. 3. ed. São Paulo: Paz e Terra, 2001. CERTEAU, Michel de. A invencao do cotidiano :artes de fazer. 2. ed. Petropolis: Vozes, 1996.

CLIFFORD, James. A experiência etnográfica : antropologia e literatura no século XX. Rio de Janeiro : Editora UFRJ, 2002.

CORBIN, Alain. Les filles de noce : misere sexuelle et prostituition : 19e et

20e siecles.Paris: Aubier Montaigne, 1978.

DURKHEIM, Émile. As formas elementares da vida religiosa :o sistema totêmico na austrália. São Paulo : Paulinas, 1989.

ECKERT, Cornélia e ROCHA, Ana Luisa. Etnografia de Rua. Illuminuras n.X,. Porto Alegre, 2002

ELIAS, Norbert. O processo civilizador. Rio de Janeiro: Jorge Zahar, 1995.

FONSECA, Claudia Lee Williams. Família, fofoca e honra : etnografia de relações

de gênero e violência em grupos populares. Porto Alegre: Ed. da UFRGS, 2000.

FOUCAULT, Michel. A microfísica do poder. Rio de Janeiro: Graal, 1995.

GOFFMAN, Erving. Estigma: notas sobre a manipulação da identidade deteriorada. 4. ed. Guanabara Koogan, 1988.

GOTTDIENER, Mark. A produção social do espaço urbano. São Paulo: Edusp, 1993.

HUXLEY, Aldous. Admirável mundo novo. 26. ed. São Paulo : Globo, 2000.

HUXLEY, Aldous. Regresso ao admirável mundo novo. São Paulo: Hemus, s.n.

MAGNI, Claudia Turra. Nomadismo urbano : uma etnografia sobre moradores de rua em Porto Alegre. 1994. 
MARX, Karl Heinrich. Manuscritos economico-filosoficos. Lisboa: Edicoes 70, 1993.

MAUSS, Marcel. Ensaio sobre a dádiva. Lisboa: Edições 70, 1988.

MELLUCI, Alberto. A invenção do presente: movimentos sociais nas sociedades complexas. Petrópolis, RJ : Vozes, 2001.

PESAVENTO, Sandra Jatahy. O imaginário da cidade : visões literárias do urbano :

Paris,Rio de Janeiro, Porto Alegre. Porto Alegre: Ed. da Universidade/UFRGS, 1999. DOUGLAS, Mary. Pureza e perigo. São Paulo: Perspectiva, 1976

NIETZSCHE, Friedrich Wilhelm. Obras incompletas. 4. ed. São Paulo: Nova Cultural, 1999. Série Os Pensadores

RUSSEL, Teresinha Dutra da. Depois do incêndio : reflexões sobre a experiência de um curso com recicladores de lixo. In: Espaços da escola. Ijuí Vol. 11, n. 42 (out./dez. 2001), p.29-43.

SCHERER-WARREN, Ilse. Redes de movimentos sociais. Sao Paulo: Loyola, 1993.

VELHO, Otávio Guilherme, (org.). O fenomeno urbano. 4. ed. Rio de Janeiro: Zahar, 1979.

VELHO, Gilberto. Individualismo e cultura: notas para uma antropologia da sociedade contemporânea. 3. ed. Rio de Janeiro: Zahar, 1994.

WEBER, Max. A ética protestante e o espírito do capitalismo. 11. ed. São Paulo: Pioneira, 1996.

ZALUAR, Alba. Maquina e a revolta: as organizações populares e o significado da pobreza. São Paulo: Brasiliense, 1985. 

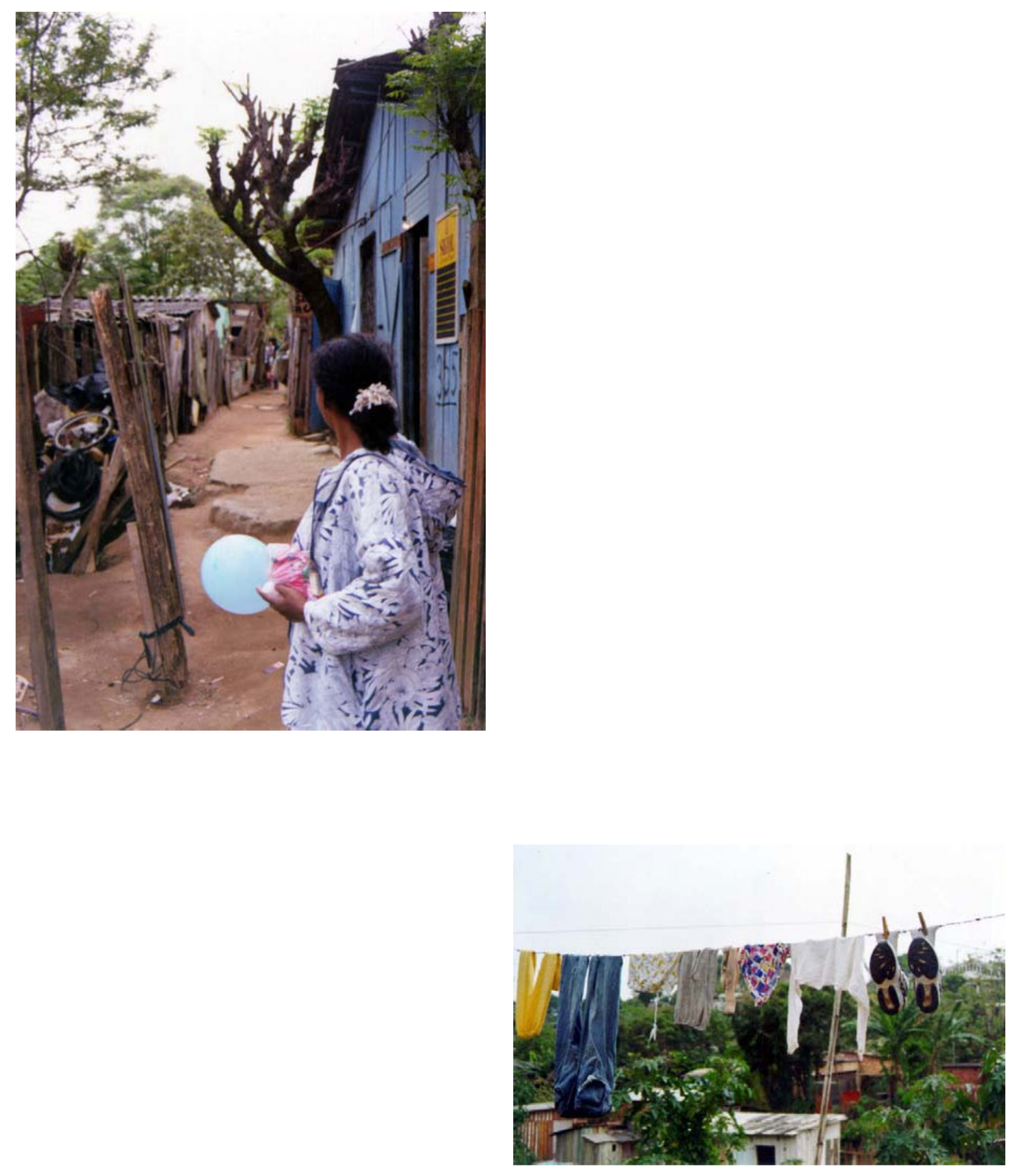

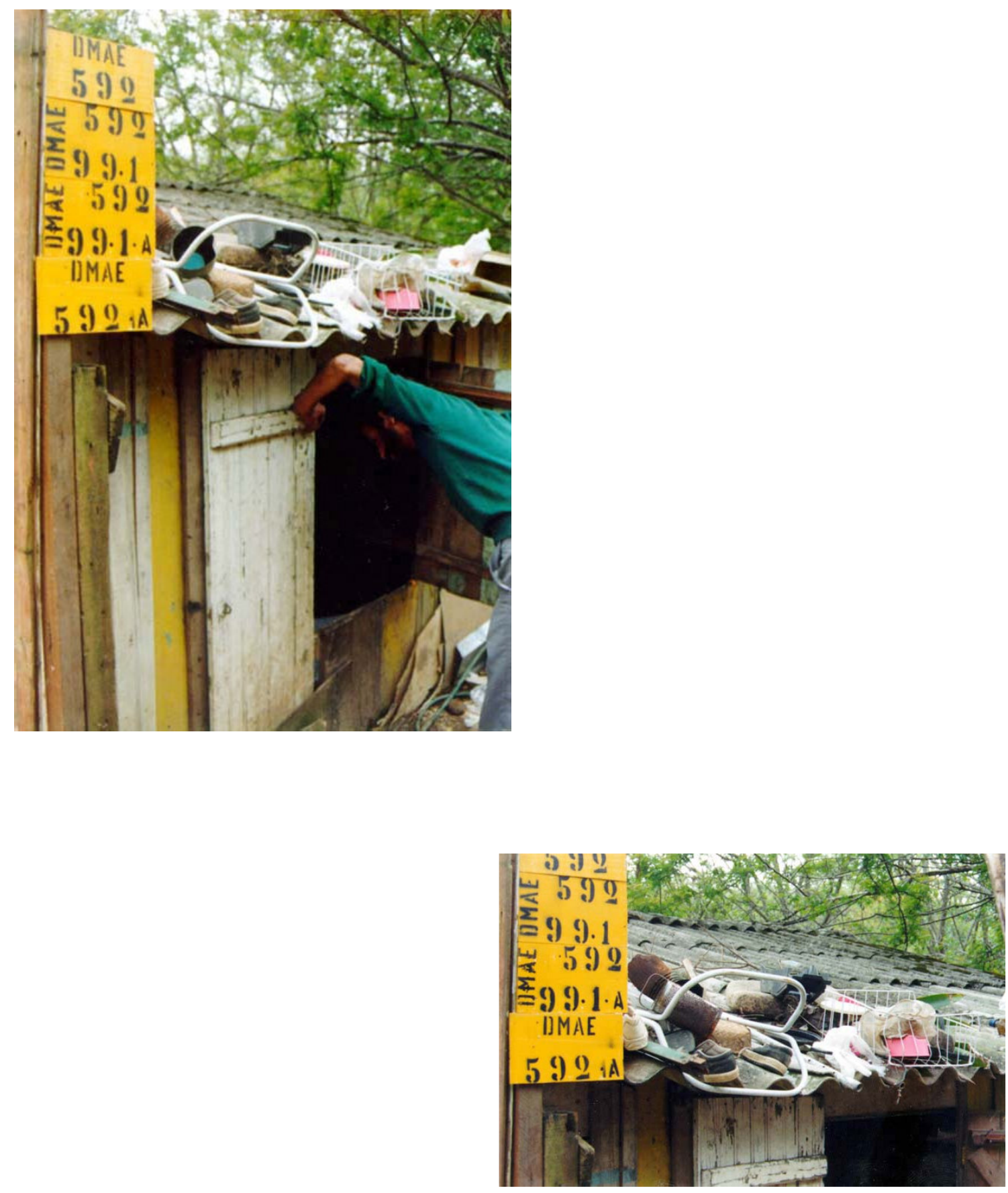

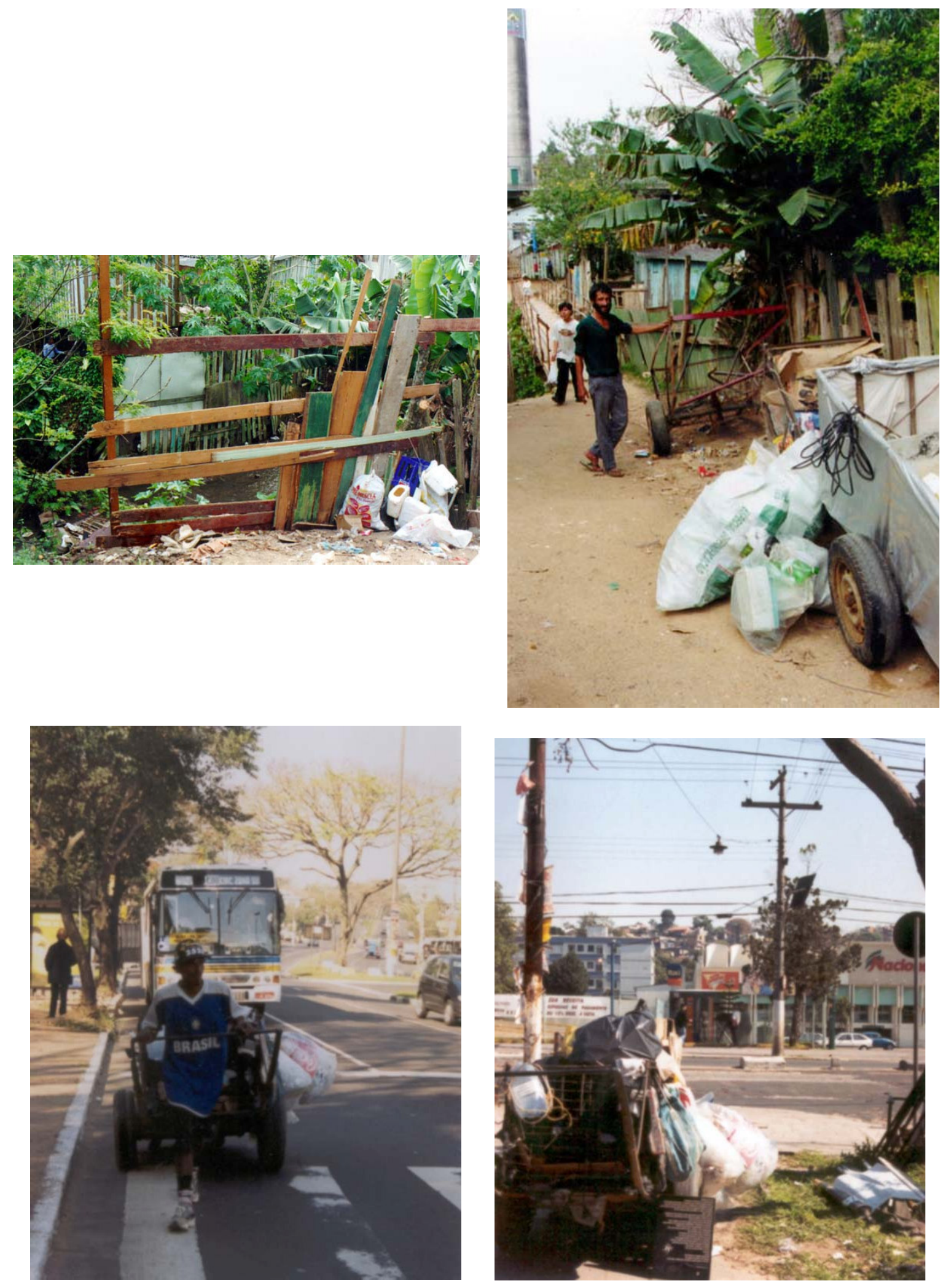